\title{
RBMS1 wt Allele
}

National Cancer Institute

\section{Source}

National Cancer Institute. RBMS1 wt Allele. NCI Thesaurus. Code C114446.

Human RBMS1 wild-type allele is located in the vicinity of $2 q 24.2$ and is approximately $222 \mathrm{~kb}$ in length. This allele, which encodes RNA-binding motif, single-strandedinteracting protein 1 , plays a role in DNA replication. 